\title{
Justice Breyer's Democratic Pragmatism
}

\section{Citation}

Cass R. Sunstein, Justice Breyer's Democratic Pragmatism, 115 Yale L.J. 1719 (2006).

\section{Published Version}

http://www.yalelawjournal.org/review/justice-breyers-democratic-pragmatism

\section{Permanent link}

http://nrs.harvard.edu/urn-3:HUL.InstRepos:12921738

\section{Terms of Use}

This article was downloaded from Harvard University's DASH repository, and is made available under the terms and conditions applicable to Other Posted Material, as set forth at http:// nrs.harvard.edu/urn-3:HUL.InstRepos:dash.current.terms-of-use\#LAA

\section{Share Your Story}

The Harvard community has made this article openly available.

Please share how this access benefits you. Submit a story.

\section{Accessibility}




\section{University of Chicago Law School Chicago Unbound}

Coase-Sandor Working Paper Series in Law and

Economics

Coase-Sandor Institute for Law and Economics

2005

\section{Justice Breyer's Democratic Pragmatism}

Cass R. Sunstein

Follow this and additional works at: http://chicagounbound.uchicago.edu/law_and_economics

Part of the Law Commons

\section{Recommended Citation}

Cass R. Sunstein, "Justice Breyer's Democratic Pragmatism" (John M. Olin Program in Law and Economics Working Paper No. 267, 2005).

This Working Paper is brought to you for free and open access by the Coase-Sandor Institute for Law and Economics at Chicago Unbound. It has been accepted for inclusion in Coase-Sandor Working Paper Series in Law and Economics by an authorized administrator of Chicago Unbound. For more information, please contact unbound@law.uchicago.edu. 


\section{CHICAGO}

John M. Olin LAW \& ECONOMics WORKING PAPER No. 267

(2D SERIES)

Public LaW ANd Legal Theory Working Paper No. 111

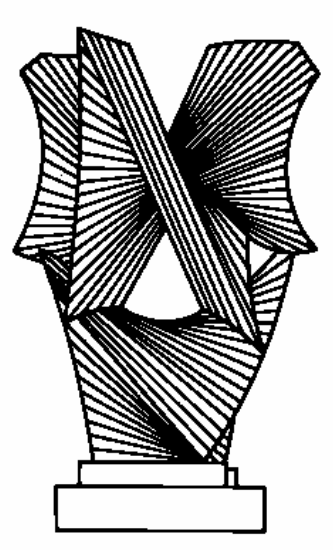

\section{JUSTICE BREYER'S DEMOCRATIC PRAGMATISM}

Cass R. Sunstein

\section{THE LAW SCHOOL THE UNIVERSITY OF CHICAGO}

November 2005

This paper can be downloaded without charge at the John M. Olin Program in Law and Economics Working Paper Series: http://www.law.uchicago.edu/Lawecon/index.html and at the Public Law and Legal Theory Working Paper Series:

http://www.law.uchicago.edu/academics/publiclaw/index.html and

The Social Science Research Network Electronic Paper Collection:

http://ssrn.com/abstract_id $=845064$ 
Preliminary draft 11/5/05

All rights reserved

Forthcoming, Yale Law Journal

\title{
Justice Breyer’s Democratic Pragmatism
}

\author{
Cass R. Sunstein
}

\begin{abstract}
There have been many efforts to reconcile judicial review with democratic self-government. Some such efforts attempt to justify judicial review if and to the extent that it promotes self-rule. Active Liberty, by Justice Stephen Breyer, is in this tradition; but it is also marked by a heavy pragmatic orientation, emphasizing as it does the need for close attention to purposes and to the importance of consequences to legal interpretation. Its distinctiveness lies in its effort to forge close connections among three seemingly disparate ideas: a democratic account of judicial review; a purposive understanding of legal texts; and a neo-pragmatic emphasis on consequences. Breyer's argument is convincing insofar as it challenges "originalist" approach on pragmatic grounds. It is more vulnerable insofar it downplays the inevitable role of judicial discretion in the characterization of purposes and the evaluation of consequences. Those who emphasize consequences, and active liberty, might well end up embracing textualism, or even broad judicial deference to legislative majorities. Moreover, it is not simple to deduce, from the general idea of "active liberty," concrete conclusions on the issues that concern Breyer, such as affirmative action, campaign finance reform, privacy rights, and commercial advertising. Many competing approaches to these issues, and to interpretation as a whole, can also march proudly under the pragmatic banner.
\end{abstract}

* Karl N. Llewellyn Distinguished Service Professor, Law School and Department of Political Science, University of Chicago Law School. This essay grows out of Cass R. Sunstein, The Philosopher-Justice, The New Republic (Sept. 19, 2005); I have substantially revised and expanded the discussion here, and in some ways the basic orientation has shifted. I am grateful to Adrian Vermeule for extremely valuable comments on a previous draft. 
The pragmatic method is primarily a method of settling metaphysical disputes that otherwise might be interminable. Is the world one or many? - fated or free?-material or spiritual?- - here are notions either of which may or may not hold good of the world; and disputes over such notions are unending. The pragmatic method in such cases is to try to interpret each notion by tracing its respective practical consequences. What difference would it practically make to any one if this notion rather than that notion were true?

-William James ${ }^{1}$

A Concise Statement of the Task

In interpreting a statute a court should:

1. Decide what purpose ought to be attributed to the statute and to any subordinate position of it which may be involved ....

It should assume, unless the contrary unmistakably appears, that the legislature was made up of reasonable persons pursuing reasonable purposes reasonably.

— Henry Hart and Albert Sacks²

\section{Preliminaries: Judicial Review and Democracy}

Throughout the nation's history, many of the most prominent constitutional theorists have tried to reconcile judicial review with the national commitment to democratic self-rule. They have argued that if the Supreme Court acts in a certain way, it can coexist comfortably with democracy after all. ${ }^{3}$ Much of this work is highly conceptual-more theoretical than pragmatic, in the sense that abstract ideas, rather than concrete consequences, are in the foreground.

Early in the twentieth century, for example, James Bradley Thayer emphasized democratic considerations in order to argue that the Supreme Court should strike down legislation only "when those who have the right to make laws have not merely made a mistake, but have made a very clear one,- - so clear that it is not open to rational

\footnotetext{
${ }^{1}$ Williams James, What Pragmatism Means, in Pragmatism (1907).

${ }^{2}$ Henry Hart and Albert Sacks, The Legal Process 1374, 1378 (William Eskridge and Philip Frickey eds. 1994).

${ }^{3}$ Some approaches, of course, insist that a constitutional democracy imposes constraints on democratic self-rule, not reducible to self-government in any way. See, e.g., Ronald Dworkin, Freedom’s Law (1996).
} 
question." ${ }^{4}$ In Thayer's view, "whatever choice is rational is constitutional." 5 Thayer believed that courts should take the same approach to challenged legislation that juries take to criminal defendants; thus he argued that the Supreme Court should uphold the actions of the elected branches unless their invalidity is "very plain and clear, clear

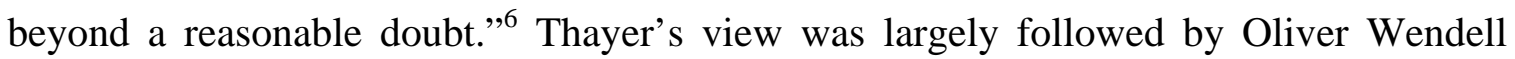
Holmes, perhaps the greatest figure in the history of American law, who generally agreed with his plea for judicial deference to the legislature. In Holmes words, "If my fellow citizens want to go to Hell I'll help them. It's my job.”7 Unlike Thayer, Holmes was inspired by pragmatism, ${ }^{8}$ but his own arguments, at least as they appeared in judicial opinions, were quite abstract. ${ }^{9}$ In the period after Franklin Delano Roosevelt's New Deal, Thayer's approach had a significant role on the Supreme Court, ${ }^{10}$ embraced as it generally was by Felix Frankfurter, ${ }^{11}$ Holmes’ disciple. ${ }^{12}$

To many people, the idea of judicial deference to the elected branches lost much of its theoretical appeal in the 1950s and 1960s, when the Supreme Court, under the leadership of Chief Justice Earl Warren, was invalidating school segregation, ${ }^{13}$ protecting freedom of speech, ${ }^{14}$ striking down poll taxes, ${ }^{15}$ requiring a rule of one person, one

\footnotetext{
${ }^{4}$ James Bradley Thayer, The Origin and Scope of the American Doctrine of Constitutional Law, 7 Harv. L. Rev. 129 (1893)

${ }^{5}$ Id.

${ }^{6}$ Id.

${ }^{7}$ Holmes to Laski, March 4, 1920, Holmes--Laski Letters, vol. 1, p. 249. The major exception to Holmes' posture of restraint was the area of free speech. See, e.g., Abrams v. United States, 250 US 616 (1919) (Holmes, J., dissenting).

${ }^{8}$ See Louis Menand, The Metaphysical Club (2002).

${ }^{9}$ See, e.g., Lochner v. New York, 198 US 45, XX (Holmes, J., dissenting). We can, however, find a highly compressed pragmatic claim in Holmes' suggestion that the Constitution "is made for people of fundamentally different views, and the accident of our finding certain opinions natural and familiar or novel and even shocking ought not to conclude our judgment upon the question whether statutes embodying them conflict with the Constitution of the United States.” The key pragmatic phrase here, and the best one, is the reference to "the accident of our finding certain opinion natural and familiar or novel and even shocking." The key pragmatic word, and the best one, is "accident."

${ }^{10}$ See, e.g., West Coast Hotel v. Parrish, 300 US 379 (1937).

${ }^{11}$ See West Virginia School District v. Barnette, 319 US 624 (1943) (Frankfurter, J., dissenting).

${ }^{12}$ There is a resemblance between Holmes' approach and the embrace of Schumpeterian democracy in Richard A. Posner, Law, Pragmatism, and Democracy 143-154 (2003). Note that Posner rejects what he sees as romantic or aspirational accounts of democracy; he sees politics in deromanticized terms, "as a competition among self-interested politicians, constituting a ruling class, for the support of the people, assumed also to be self-interested, and to be none too interested in or well informed about politics." Breyer's more aspirational conception of politics is in a very different spirit; see in particular the emphasis on participation (pp. 134-35).

${ }^{13}$ See Brown v. Bd. of Educ., 347 US 483 (1954).

${ }^{14}$ See Brandenburg v. Ohio. 395 US 444 (1969).
} 
vote, ${ }^{16}$ and protecting accused criminals against police abuse. ${ }^{17}$ Is it possible to defend the Warren Court against the charge that its decisions were fatally undemocratic? The most elaborate effort came from John Hart Ely, the Warren Court's most celebrated expositor and defender, who famously argued for what he called a "representationreinforcing” approach to judicial review. ${ }^{18}$ Like Thayer, Ely emphasized the central importance of democratic self-rule. But Ely famously insisted that if self-rule is really our loadstar, then unqualified judicial deference to legislatures is utterly senseless. Some rights, Ely argued, are indispensable to self-rule, and the Court legitimately protects those rights not in spite of democracy but in its name. ${ }^{19}$ The right to vote and the right to speak are the central examples. Courts promote democracy when they protect those rights.

Ely went much further. He argued that some groups are at a systematic disadvantage in the democratic process, and that when courts protect "discrete and insular minorities," they are reinforcing democracy too. ${ }^{20}$ Ely was particularly concerned with African-Americans, whom he saw as unable to protect themselves in politics. But with some qualifications, his plea for judicial protection extended to other groups as well. ${ }^{21}$ And while Ely was clearly concerned with consequences, his argument stressed democracy's preconditions, and indeed the general idea of equal concern and respect. ${ }^{22}$

A third theory of constitutional interpretation, stressed most prominently by Justice Antonin Scalia ${ }^{23}$ and also favored by Clarence Thomas, ${ }^{24}$ is "originalism." Invoking both self-government and the rule of law, originalists believe that the Constitution should be interpreted to mean what it meant at the time that it was ratified. If the Equal Protection Clause was originally understood to permit sex discrimination, then courts should permit sex discrimination. If the Second Amendment was originally understood to forbid gun control, then courts should forbid gun control. When President

\footnotetext{
${ }^{15}$ Harper v. Bd. of Elections, 383 US 663 (1966).

${ }^{16}$ Reynolds v. Sims, 377 US 533 (1964).

${ }^{17}$ See Miranda v. Arizona, 384 US 436 (1966).

${ }^{18}$ See John Hart Ely, Democracy and Distrust 181 (1983).

${ }^{19}$ Id. at $105-34$.

${ }^{20}$ See id. at $135-177$.

${ }^{21}$ Id. at $160-70$.

${ }^{22}$ Id. at 82.

${ }^{23}$ See Antonin Scalia, A Matter of Interpretation (1997); Antonin Scalia, Originalism: The Lesser Evil, 57 U Cin L Rev 849 (1989).

${ }^{24}$ See, e.g., Elk Grove Unified School Dist v. Newdow, 542 US 1, XXYY (2004) (Thomas, J., dissenting).
} 
Bush praises “strict construction,” many people take him to be embracing originalism. ${ }^{25}$ Originalists like Scalia do not follow Thayer's approach, because they are quite prepared to strike down legislation that violates the original understanding. Originalists do not defend Ely's idea of “representation-reinforcing” judicial review. But in their own way, originalists too prize democracy. They emphasize that the Constitution was ratified by We the People, who have sovereign authority, and they want to limit the discretion of federal judges, who are after all unelected. ${ }^{26}$

It is true that those who ratified the Constitution are long dead, and this point might be thought to create a real problem for originalists who attempt to defend their approach on democratic grounds. Why-in the name of self-government?-should current citizens be bound by those who lived long ago? But democracy is central to originalist thinking about constitutional law. ${ }^{27}$ Above all, originalists fear that if judges do not follow the original understanding, they will be creating the Constitution anew, because they will give it the content of their own choosing. Originalist arguments are not always pragmatic in spirit. On the contrary, they can be highly abstract, stressing considerations of legitimacy. ${ }^{28}$ But some originalists are aware that their approach would have dramatic and perhaps intolerable consequences. $^{29}$ Inspired by pragmatic considerations, they are willing to attempt to reduce that risk. ${ }^{30}$

${ }^{25}$ Mona Charen, Do-Gooders: How Liberals Hurt Those They Claim to Help (and The Rest of Us) (2004).

${ }^{26}$ See Scalia, A Matter of Interpretation, supra note.

${ }^{27}$ See Cass R. Sunstein, Justice Scalia’s Democratic Formalism, 107 Yale LJ 529 (1997).

${ }^{28}$ See Robert Bork, The Tempting of America (1985); some of the arguments in Scalia, A Matter of Interpretation, are in the same vein. Consider this passage: "The principal theoretical defect of nonoriginalism, in my view, is its incompatibility with the very principle that legitimizes judicial review of constitutionality. .. . I take the need for theoretical legitimacy seriously, and even if one assumes (as many nonoriginalists do not even bother to do) that the Constitution was originally meant to expound evolving rather than permanent values, . . . I see no basis for believing that supervision of the evolution would have been committed to the courts. At an even more general theoretical level, originalism seems to me more compatible with the nature and purpose of a Constitution in a democratic system."

${ }^{29}$ See Scalia, The Lesser Evil, supra note: "I can be much more brief in describing what seems to me the second most serious objection to originalism: In its undiluted form, at least, it is medicine that seems too strong to swallow. Thus, almost every originalist would adulterate it with the doctrine of state decisis-so that Marbury v. Madison would stand even if Professor Raoul Berger should demonstrate unassailably that it got the meaning of the Constitution wrong. . . . But stare decisis alone is not enough to prevent originalism from being what many would consider too bitter a pill. What if some state should enact a new law providing public lashing, or branding of the right hand, as punishment for certain criminal offenses? Even if it could be demonstrated unequivocally that these were not cruel and unusual measures in 1791, and even though no prior Supreme Court decision has specifically disapproved them, I doubt whether any 


\section{Pragmatism, Consequences, and Active Liberty}

As a law professor at Harvard Law School, Stephen Breyer specialized in administrative law. His important work in that field was marked above all by its unmistakably pragmatic foundations. ${ }^{31}$ Indeed, one of his major innovations lay in an insistence on the importance of evaluating traditional doctrines not in a vacuum, but in light of the concrete effects of regulation on the real world. ${ }^{32}$ Hence Breyer argued for a close connection between administrative law and regulatory policy. ${ }^{33}$ While some of his work touched on the separation of powers, ${ }^{34}$ constitutional law was not his field. But as a member of the Supreme Court, Breyer has slowly been developing a distinctive approach of his own, one that also has a pragmatic dimension, and that can be seen as directly responsive to his colleague Scalia and to originalism.

This book announces and develops that theory. Its most distinctive feature is its effort to connect three seemingly disparate claims. The first is an insistence that judicial review can and should be undertaken with close reference to active liberty and to democratic goals, a point with clear links to Ely's work. The second is an emphasis on the centrality of "purposes" to legal interpretation, a point rooted in the great legal process materials of Henry Hart and Albert Sacks and in particular their brilliant note on statutory interpretation. ${ }^{35}$ The third is a claim about the need to evaluate theories of legal interpretation with close reference to their consequences, a point whose foundations can be found in American pragmatism. ${ }^{36}$

As we shall see, much of the interest of Breyer's book lies in its effort to integrate these three claims. I shall be raising questions about that effort, above all on two grounds.

federal judge--even among the many who consider themselves originalists-- would sustain them against an eighth amendment challenge."

${ }^{30}$ Note here that Justice Scalia confesses, "I hasten to confess that in a crunch I may prove a fainthearted originalist. I cannot imagine myself, any more than any other federal judge, upholding a statute that imposes the punishment of flogging." See id.

${ }^{31}$ See, e.g., Stephen Breyer, Regulation and its Reform (1985).

${ }^{32}$ See, e.g., id; Stephen Breyer, Breaking the Vicious Circle (1993).

${ }^{33}$ See Stephen Breyer et al., Administrative Law and Regulatory Policy ( $6^{\text {th }}$ ed. 2006). Full disclosure: I am among the "al." now working on the book, and hence Breyer and I are, in a formal sense, coauthors. But Breyer, otherwise occupied, has not worked on the book since I have joined it.

${ }^{34}$ See Stephen Breyer, The Legislative Veto After Chadha, 72 Geo LJ 785 (1984).

${ }^{35}$ See Henry Hart and Albert Sacks, The Legal Process 1340-48 (William Eskridge and Philip Frickey eds. 1994)

${ }^{36}$ See William James, Pragmatism (1907). 
First, those who emphasize active liberty and democratic self-government might well reject a purposive approach to interpretation, including purposive interpretation of the Constitution. Second, those who believe in the importance of consequences might well be drawn to an approach very different from Breyer's, including textualism, Thayerism, and perhaps even originalism. Breyer's arguments are unfailingly reasonable; the question is whether his general commitments are enough to justify his particular conclusions. Let us now turn to some details.

\section{A. Theory}

Breyer's organizing theme is "active liberty," which he associates with the right of self-governance. It is noteworthy that in his own judicial work, Breyer is plausibly seen as the most consistently democratic member of the Rehnquist Court: Among its nine members, he has shown the highest percentage of votes to uphold acts of Congress ${ }^{37}$ and also to defer to the decisions of the executive branch. ${ }^{38}$ And indeed, a great deal of his book is a plea for judicial caution and deference. ${ }^{39}$ But Breyer does not mean to follow Thayer; he does not say that the Court should uphold legislation whenever the Constitution is unclear. Like Ely, Breyer does not rule out the view that courts should take an aggressive role in some areas, above all in order to protect democratic governance (p. 11).

His short book comes in three parts. The first builds on Benjamin Constant's famous distinction between the liberty of the ancients and the liberty of the moderns (pp. $3-7){ }^{40}$ The liberty of the ancients involves "active liberty"-the right to share in the exercise of sovereign power. Quoting Constant, Breyer refers to the hope that the sharing of that power would "ennoble" the people's "thoughts and establish among them a kind of intellectual equality which forms the glory and power of a free people” (p. 4). But Constant also prized negative liberty, meaning “individual independence” from government authority. As Breyer describes Constant's view, which he firmly endorses, it

\footnotetext{
${ }^{37}$ Lori Ringhand, Judicial Activism and the Rehnquist Court, available on ssrn.com.

${ }^{38}$ See Cass R. Sunstein and Thomas Miles, Do Judges Make Regulatory Policy? An Empirical Investigation of Chevron, U Chi L Rev (forthcoming 2006).

39 Thus, for example, Breyer favors a deferential approach to campaign finance restrictions and affirmative action programs; he also makes a plea for judicial caution in the domain of privacy.

${ }^{40}$ The best discussion remains Stephen Holmes, Benjamin Constant and the Making of Modern Liberalism (1984).
} 
is necessary to have both forms of freedom, and thus "to combine the two together" (p. 5). ${ }^{41}$

Breyer believes that the founders of the Constitution did exactly that. His special emphasis is on what Constant called "an active and constant participation in public power. ${ }^{42}$ That form of participation includes voting, town meetings, and the like; but it also requires that citizens receive information and education, in order to promote their capacity to ensure effective governance. In Breyer's view, the citizens of postrevolutionary America insisted on highly democratic forms of state government, promoting popular control. Breyer is aware of the highly ambivalent experiences of postrevolutionary governments; he know that some commentators have rejected the view that the Constitution is a democratic document. ${ }^{43}$ Nonetheless, he believes that the founders of the Constitution accepted the deepest aspirations of the American Revolution, creating a framework with a "basically democratic outlook" (p. 25).

After all, the document begins with the words, "We the People," and in Breyer's view, its very structure is a testimonial to active liberty. Both the House and the Senate are subject to electoral control. Even with the electoral college, the choice of the President is ultimately traceable to voters, not to an unaccountable elite. Breyer thinks that the whole system is "difficult to reconcile with a retreat from democratic principle." On the contrary, he claims that the Constitution can be viewed "as focusing first and foremost upon 'active liberty.'” He thinks that constitutional interpretation should be undertaken with close reference to that overriding constitutional purpose. ${ }^{44}$

In Breyer's account, the Warren Court appreciated active liberty, and it attempted to make that form of liberty more real for all Americans (p. 11). By contrast, the Rehnquist Court may have pushed the pendulum too far back in the other direction (id.). In short, Breyer believes that an appreciation of active liberty has concrete implications for a wide range of modern disputes.

\footnotetext{
${ }^{41}$ It is not clear that this is, in fact, an adequate account of Constant's view. See Holmes, supra note.

${ }^{42}$ See also Frank Michelman, Politics and Values or What's Really Wrong with Rational Basis Review, 13 Creighton L Rev 487 (1979).

${ }^{43}$ See, e.g., Charles Beard, An Economic Interpretation of the Constitution of the United States (1913).

${ }^{44}$ As we shall see this claim is best taken, not as purely historical, but as an interpretive claim, one that attempts both to fit the document and to place it in the best constructive light. See Ronald Dworkin, Law's Empire (1985).
} 


\section{B. Applications}

The second part of his book traces those implications. He begins with free speech. An obvious question is whether the Court should be hostile or receptive to campaign finance reform. With his eye directly on the democratic ball, Breyer suggests that if we focus on the "the Constitution's basic structural objective, 'participatory selfgovernment'” (p. 46), then we will be receptive to restrictions on campaign contributions. A central reason is that such restrictions "seek to democratize the influence that money can bring upon the electoral process” (p. 47). He thinks that some of his colleague s, most prominently Rehnquist and Scalia, have been quite mistaken to invoke negative liberty as a rigid barrier to campaign finance restrictions. In the same vein, he insists that the free speech principle, seen in terms of active liberty, gives special protection to political speech, and significantly less protection to commercial advertising. He criticizes his colleagues on the Court for protecting advertising with the aggressiveness that they have shown in recent years. His purposive interpretation of freedom of speech thus emphasizes democratic self-government above all. ${ }^{45}$

Affirmative action might seem to have little to do with active liberty. At first glance, it poses a conflict between the ideal of color-blindness and what Breyer calls a "narrowly purposive" (p. 80) understanding of the Equal Protection Clause, one that emphasizes the historical mistreatment of African-Americans. Directly disagreeing with some of his colleagues, ${ }^{46}$ Breyer endorses the narrowly purposive approach. But he also contends that in permitting affirmative action at educational institutions, the Court has been centrally concerned with democratic self-government. The reason, pragmatic in character, is that "some form of affirmative action" is "necessary to maintain a wellfunctioning participatory democracy" (p. 81). Breyer points to the Court's emphasis on the role of broad access to education in "sustaining our political and cultural heritage" and in promoting diverse leadership. Underlining those points, Breyer argues that the Court's decision to permit affirmative action made a direct appeal "to principles of fraternity, to principles of active liberty” (p. 82). In Breyer's view, it should be no

\footnotetext{
${ }^{45}$ In this way he seems to follow Alexander Meiklejohn, Free Speech and its Relation to SelfGovernment (1948); Cass R. Sunstein, Democracy and the Problem of Free Speech (1993), is in the same general vein.

${ }^{46}$ See, e.g., Gratz v. Bollinger, 539 US 244 (2003) (Thomas, J., dissenting).
} 
surprise that the Court selected an interpretation of the Equal Protection Clause that would, as a pragmatic matter, promote rather than undermine the operation of democracy. As serious problem with the attack on affirmative action is that it would produce intolerable consequences.

With respect to privacy, Breyer's emphasis is on the novelty of new technologies and the rise of unanticipated questions about how to balance law enforcement needs against the interest in keeping personal information private. Because of the difficulty of those problems, Breyer argues, on pragmatic grounds, for "a special degree of judicial modesty and caution.” He wants to avoid a "premature judicial decision” that would risk "short-circuiting, or pre-empting, the 'conversational law-making process.” Hence his plea is for narrow, cautious judicial rulings that do not lay out long-term solutions. In Breyer's view, such rulings serve active liberty, because they refuse to "limit legislative options in ways now unforeseeable.” By its very nature, a narrow ruling is unlikely to “interfere with any ongoing democratic policy debate.” His argument here is important, because other members of the Court, most notably Scalia, have objected to narrow rulings on the ground that they leave too much uncertainty for the future. ${ }^{47}$

Some of the most noteworthy decisions of the Rehnquist Court have attempted to limit the power of Congress. ${ }^{48}$ For example, the Court has struck down the Violence Against Women Act as beyond congressional authority under the Commerce Clause. ${ }^{49}$ It has also announced an "anti-commandeering” principle, one that forbids the national government from requiring state legislatures to enact laws. ${ }^{50}$ In the abstract, those decisions seem to promote active liberty, because they decrease the authority of the more remote national government, and because they promote participation and self-government at the local level. Breyer is no critic of federalism or defender of centralized government. He agrees that the federal system fits with his general theme, because that system makes "it easier for citizens to hold government officials accountable" and because it brings “government closer to home.”

\footnotetext{
${ }^{47}$ See, e.g. Antonin Scalia, The Rule of Law is a Law of Rules, 56 U Chi L Rev 1175 (1989).

${ }^{48}$ United States v. Morrison, 529 US 598 (2000).

${ }^{49}$ Id

${ }^{50}$ New York v US, 505 US 144 (1992).
} 
Nonetheless, he strongly objects to the Court's recent federalism decisions. With respect to congressional enactments, "the public has participated in the legislative process at the national level, " and hence active liberty calls for deference by the Court. Breyer's special target is the anti-commandeering principle. Speaking in heavily pragmatic terms, Breyer thinks that this prohibition prevents valuable national initiatives to protect against terrorism, environmental degradation, and natural disasters-initiatives in which, for example, the national government requires state officials to ensure compliance with federal standards (p. 60).

Breyer also contends that an understanding of active liberty can inform more technical debates. Here is a prominent example: In Chevron v. NRDC, ${ }^{51}$ the Court announced a principle of deference to administrative interpretations of law. The Court ruled that in the face of statutory ambiguity, courts should defer to agency interpretations so long as they are reasonable. Breyer believes that this approach is too simple and too crude, in a way that disserves democracy itself. ${ }^{52}$ When the agency has solved an interstitial question, Breyer believes that judicial deference is appropriate, because deference is what a reasonable legislature would want. But on "questions of major importance” (p. 107), involving the fundamental reach or nature of the statute, Breyer thinks that a reasonable legislature would not want courts to accept the agency's interpretation. He thus urges that courts should take a firmer hand in reviewing agency judgments on fundamental matters than in reviewing more routine matters. Here too, he opposes Justice Scalia, who endorses a broad reading of Chevron, one that would generally defer to agency interpretations of law. ${ }^{53}$ In democracy's name, Breyer argues on behalf of independent judicial review of agency interpretations involving major national questions.

There is a larger interpretive question in the background. Should courts rely only on a statute's literal text, or should they place an emphasis instead “on statutory purpose and congressional intent”? Sharply disagreeing with the more textually-oriented Scalia, ${ }^{54}$

\footnotetext{
51467 US 837 (1984).

52 See Stephen Breyer, Judicial Review of Questions of Law and Policy, 38 Admin L Rev 363 (1986); see also Cass R. Sunstein, Chevron Step Zero, Va L Rev (forthcoming).

${ }^{53}$ See Antonin Scalia, Judicial Deference to Agency Interpretations of Law, 1989 Duke LJ 511; United States v. Mead, 533 US 218 (2001) (Scalia, J., dissenting).

${ }^{54}$ See Antonin Scalia, A Matter of Interpretation, supra note.
} 
and again emphasizing pragmatic considerations, Breyer favors purpose and intent. Here he is evidently influenced by the famous legal process materials, compiled by Henry Hart and Albert Sacks; as I have noted, those materials place "purpose” front and center, and they also insist that courts should assume that legislators are "reasonable people acting reasonably." 55 In the same vein, Breyer emphasizes that a purpose-based approach asks courts to consider the goals of "the 'reasonable Member of Congress'-a legal fiction that applies, for example, even when Congress did not in fact consider a particular problem."56

In defending this approach, Breyer speaks in thoroughly pragmatic terms, emphasizing the beneficial consequences of purposivism. Breyer thinks that as compared with a single-minded focus on literal text, his approach will tend to make the law more sensible, almost by definition. He also contends that it "helps to implement the public's will and is therefore consistent with the Constitution's democratic purpose." Breyer concludes that an emphasis on legislative purpose "means that laws will work better for the people they are presently meant to affect. Law is tied to life; and a failure to understand how a statute is so tied can undermine the very human activity that the law seeks to benefit” (p. 100). Thus Breyer directly links active liberty, purposive approaches to law, and an emphasis on consequences.

The third part of Breyer's book tackles the broadest questions of interpretive theory and directly engages Scalia's contrary view. Breyer explicitly emphasizes that he means to draw attention to purposes and consequences above all. Constitutional provisions, he thinks, have "certain basic purposes," and they should be understood in light of those purposes and the broader democratic goals that infuse the Constitution as a whole. In addition, consequences are "an important yardstick to ensure a given interpretation's faithfulness to these democratic purposes.” Breyer is fully aware that many people, including his colleagues Scalia and Thomas, are drawn to "textualism" and its close cousin "originalism"-approaches that argue in favor close attention to the

\footnotetext{
${ }^{55}$ See Hart and Sacks, supra note, at 1380.

${ }^{56}$ See the powerful note, emphasizing this point and what the authors saw as the centrality of purpose, in Henry Hart and Albert Sacks, The Legal Process 1374-1380 (William Eskridge and Philip Frickey eds. 1994). Thus Hart and Sacks offer "A Concise Statement of the Task," which begins, "Decide what purpose ought to be attributed to the statute and to any subordinate provision of it which may be involved," id at 1374 , and add that a court "should assume, unless the contrary unmistakably appears, that the legislature was made up of reasonable persons pursuing reasonable goals reasonably,” id. at 1378.
} 
meaning of legal terms at the time that were enacted. Scalia , Thomas, and their followers are likely to think that Breyer's approach is an invitation for open-ended judicial lawmaking, in a way that compromises his own democratic aspirations. ${ }^{57}$ But he offers several responses.

First, originalist judges claim to follow history, but they cannot easily demonstrate that history in fact favors their preferred method. The Constitution does not say that it should be interpreted to mean what it meant when it was ratified. The document itself enshrines no particular theory of interpretation; it does not mandate originalism. And if originalism cannot be defended by reference to the intentions and understandings of the framers, Breyer asks, in what way can it be defended- - "other than in an appeal to consequences?” He points out that the most sophisticated originalists ultimately argue that their approach will have good consequences-by, for example, stabilizing the law and deterring judges from imposing their own views. Even Breyer's originalist adversaries are "consequentialist in an important sense" (p. 118). They are not consequentialists in particular cases, but they adopt, and defend, their preferred approach on consequentialist grounds. ${ }^{58}$

Breyer's second argument is that his own approach does not leave courts at sea, for he too insists that judges must take account of "the legal precedents, rules, standards, practices, and institutional understanding that a decision will affect.” Those who focus on consequences will not favor frequent or dramatic legal change, simply because stability is important. In any case textualism and originalism cannot avoid the problem of judicial discretion. "Which historical account shall we use? Which tradition shall we apply?” (p. 127). In the end, Breyer contends that the real problem with textualism and originalism is that they "may themselves produce seriously harmful consequences-outweighing whatever risks of subjectivity or uncertainty [are] inherent in other approaches” (p. 129). His pragmatic goal is "a form of democratic government that will prove workable over

\footnotetext{
${ }^{57}$ See Scalia, Originalism: The Lesser Evil, supra note.

${ }^{58}$ See id; see also the candid suggestion by Randy Barnett, a self-described originalist, see Randy Barnett, Restoring the Lost Constitution (2004): "Given a sufficiently good constitutional text, originalists maintain that better results will be reached overall if government officials-including judges-must stick to the original meaning rather than empowering them to trump that meaning with one that they prefer," available at http://legalaffairs.org/webexclusive/debateclub_cie0505.msp (emphasis added).
} 
time,” and he believes that his kind of purposive approach, rooted in active liberty, is most likely to promote that goal.

\section{Characterizing Purposes or Ensuring Active Liberty? Some Pragmatic Questions}

This is a brisk, lucid, and energetic book, written with conviction and offering a central argument that is at once provocative and appealing. It is not usual for a member of the Supreme Court to attempt to set out a general approach to his job; Breyer's effort must be ranked among the very few most impressive such efforts in the nation's long history. And in defending a pragmatic, purposive-oriented alternative to originalism, Breyer writes in a way that is unfailingly civil and generous to those who disagree with him-and thus provides a model for how respectful argument might occur, even in a domain that is intensely polarized.

A large difficulty, as we shall soon see, lies in the characterization of purposes, both in particular cases and in general. Texts rarely announce their own purposes; the same is true of the Constitution itself. When Breyer asks judges to identity the purposes of reasonable legislators, he is inviting a degree of judicial discretion in the judgment of what purposes are reasonable. And while he is not wrong to say that "active liberty" helped inform the founding document, his own characterization of its purposes has a strong evaluative element. The same is true for the effort to bring active liberty to bear on concrete cases.

There is a further point. Breyer emphasizes consequences, and rightly so. But those who think that consequences are important might well end up favoring approaches that he rejects, such as textualism, judicial deference to legislative judgments, ${ }^{59}$ respect for agency interpretations of law, and even originalism. To be sure, consequences cannot be assessed without some theory of value, and Breyer wants to use active liberty as part of the standard for assessment. But it is both to impossible both to use active liberty as the basis for evaluating consequences and to think that courts do best if they follow the ordinary meaning of statutory texts, or defer to agency interpretations of the most important questions, or uphold legislation unless it is plainly unconstitutional.

\footnotetext{
${ }^{59}$ For a consequentialist defense of such deference, see Adrian Vermeule, Judging Under Uncertainty (forthcoming 2006.
} 
I do not believe that these are decisive objections to Breyer's particular conclusions or even to his general approach. But they suggest that the defense of those conclusions, and of that approach, must be cast in a way that acknowledges that much of the time, reasonable purposes are made, not found. And on both pragmatic and democratic grounds, that acknowledgement raises some questions about the search for purposes by the federal judiciary. It is possible that we are all pragmatists now. ${ }^{60}$ If so, the problem is that many different approaches, and not only Breyer's, can march under the pragmatic banner. ${ }^{61}$ Breyer does not give adequate attention to the possibility that alternative approaches, especially in the domains of statutory interpretation and administrative law, might be powerfully defended on the very grounds that Breyer invokes.

\section{A. Originalism and Consequences}

Breyer's specific conclusions do make a great deal of sense; they are eminently reasonable. In the domain of personal privacy, for example, the Court should be aware of how little it knows about current technological developments, and narrow rulings have the valuable feature of avoiding premature solutions. ${ }^{62}$ In general, Breyer makes a sensible plea for judicial restraint, and it is most illuminating to hear that plea from one of the Court's “liberals.” Indeed, Breyer’s survey of particular areas is unified by a general theme, which involves the need for courts to respect democratic prerogatives. But his largest claim is more general still: Any approach to legal interpretation must be defended

\footnotetext{
${ }^{60}$ Note in this connection that Judge Richard Posner is a famous pragmatist, and his own approach to law is very different from Justice Breyer's, certainly insofar as Posner does not stress citizen participation or active liberty. See Richard A. Posner, Law, Pragmatism, and Democracy 57-96 (2003); Richard A. Posner, Foreword, Harv L Rev (forthcoming 2005). Posner describes his own position as "everyday pragmatism," id. at 24-25, 49-56, as distinguished from philosophical pragmatism, and Posner tries to avoid theoretically ambitious claims. He describes everyday pragmatism as "the untheorized cultural outlook of most Americans, one rooted in the usages and attitudes of a brash, fast-moving, competitive, forwardlooking, commercial, materialistic, philistine society, with its emphasis on working hard and getting ahead." An obvious objection to "untheorized" pragmatism is that it is not possible to evaluate consequences without a contested judgment of value; and Posner's own description of the "untheoretized culture outlook of most Americans" does suggest some kind of theoretical position. But this objection should not be overstated. It is often possible, however, for people to make a particular evaluation of consequences amidst disagreement or uncertainty about foundational questions. See Cass R. Sunstein, Legal Reasoning and Political Conflict (1996).

${ }^{61}$ See, e.g., Adrian Vermeule, Judging Under Uncertainty (forthcoming 2006), which defends a form of Thayerism on pragmatic grounds.

${ }^{62}$ See Lawrence Lessig, The Path of Cyberlaw, 104 Yale LJ 1743 (1995).
} 
in a way that plays close attention to its consequences. Despite its simplicity, this pragmatic point continues to be widely ignored. It has particular implications for the analysis of originalism.

Of course there is a lively historical dispute about whether those who ratified the Constitution meant to hold posterity to their specific views. ${ }^{63}$ If the ratifiers did not want to bind posterity to their particular understandings, originalism stands defeated on its own premises: The original understanding may have been that the original understanding is not binding. Breyer properly notes this possibility (p. 117), and if the historical record shows that the ratifiers rejected originalism, the argument for originalism is selfdefeating. But suppose that the ratifiers had no clear view on that question, or even that the better understanding is that they did, in fact, want to hold posterity to their understandings. ${ }^{64}$ Even if so, it is up to us, and not to them, to decide whether to follow those views. It would be circular and therefore unhelpful to defend reliance on the ratifiers' specific views on the ground that the ratifiers wanted us to respect their specific views.

It follows that the question whether originalism is a sensible approach to constitutional law must be answered by reference to its consequences. ${ }^{65}$ Suppose that the consequence of originalism would be to threaten many contemporary rights and understandings. If so, why should we accept it ${ }^{66}$ ? And indeed it does seem probable that originalism would have this consequence. For example, it would likely mean that the national government could discriminate on the basis of race and sex, simply because the equal protection clause does not apply to the national government at all. Originalism would almost certainly authorize states to discriminate on the basis of sex, which the equal protection clause was not originally understood to forbid. Originalism might well mean that Brown v. Bd of Education was wrongly decided ${ }^{67}$; it would almost certainly

${ }^{63}$ See Caleb Nelson, Originalism and Interpretive Conventions, 70 U Chi L Rev 519 (2003); H. Jefferson Powell, The Original Understanding of Original Intent, 99 Harv L Rev 885 (1985).

${ }^{64}$ See Nelson, supra note.

${ }^{65}$ Of course any evaluation of consequences must be value-laden, a point taken up below.

66 See Richard A. Posner, Bork and Beethoven, 42 Stan L Rev 1365 (1990).

${ }^{67}$ The reason is that it is not easy to find, in the fourteenth amendment, a specific understanding that any relevant clause banned segregation. See Frank and Munro, The Original Understanding of the Equal Protection of the Laws, 1972 Wash Q L Rev 421, 460-62; R. Berger, Government by Judiciary 123-125 (1977); A. Bickel, The Original Understanding and the Segregation Decision, 69 Harv L Rev 1, 11-40 (1955). For a counterargument, see Michael McConnell, Originalism and the Desegregation Decisions, 81 
eliminate the right of privacy altogether, simply because there is no such right in the document, and it is hard to show that the original understanding of any relevant provision supports the privacy right. And many originalists firmly believe that their approach would require courts to invalidate a great deal of legislation-by, for example, striking down independent regulatory agencies, ${ }^{68}$ forbidding Congress from delegating discretion to regulatory agencies, ${ }^{69}$ and imposing new limitations on national power under the commerce clause. ${ }^{70}$

I do not mean to say that the originalist method necessarily compels all of these conclusions; the interpretive questions are complex, not simple. And even if originalism has these consequences, some originalists candidly acknowledge that established precedent has its claims, and that it must sometimes be respected even if it deviates from the original understanding. Justice Scalia, for example, says that he might well be a "faint-hearted" originalist, ${ }^{71}$ because he is willing to follow precedent even when he believes that it is wrong in principle. ${ }^{72}$ My only point is that Breyer is correct to note that the document itself does not require originalism and to argue that consequences matter to the choice of a theory of interpretation-and to insist that if we care about consequences, the argument for originalism looks increasingly implausible. ${ }^{73}$

Va L Rev 947 (1995). McConnell impressively shows that many members of Congress believed that under section five of the fourteenth amendment, Congress had the authority to abolish segregation. But it is one thing to say that many members of Congress so believed, and expressed that view in unenacted legislation; it is quite another thing to say that the fourteenth amendment was understood to create a self-executing, judicial enforceable ban on segregation.

${ }^{68}$ Steven Calabresi and Sai Prakash, The President’s Power to Execute the Law, 104 Yale LJ 541 (1994).

${ }^{69}$ Randolph May, The Public Interest Standard: Is It Too Indeterminate to be Constitutional, $53 \mathrm{~F}$ Comm LJ 427 (2001).

${ }^{70}$ See Raich v. Ashcroft, US (Thomas, J., dissenting); Richard Epstein, The Proper Scope of the Commerce Clause, 73 Va L Rev 1387 (1987); Randy Barnett, Restoring the Lost Constitution (2003); Douglas Ginsburg, On Constitutionalism, Cato Supreme Court Review 7 (2003).

${ }_{72}^{71}$ Scalia, A Matter of Interpretation, supra note.

${ }^{72}$ Scalia has said that Thomas "doesn't believe in stare decisis, period." Scalia remarks, "if a constitutional authority is wrong, [Thomas] would say, 'Let's get it right.' I wouldn't do that.” Quoted in Stephen Presser, Touting Thomas, Legal Affairs (Jan./Feb. 2005).

${ }^{73}$ There are other problems, including the arguable incoherence of the originalist enterprise. See Cass R. Sunstein, Radicals in Robes (2005). 


\section{B. Second-Order Pragmatism? Of Purposes and Texts}

Breyer offers a sketch, not a sustained argument, and he leaves significant gaps. Above all, he says too little about the difficulties that judges face in assessing consequences and in describing purposes. We can describe this as a pragmatic objection to his approach—an objection that might argue in favor of second-order pragmatism, that is, a form of pragmatism that is alert to institutional considerations. ${ }^{74}$ Let us begin with some technical issues.

Recall that Breyer argues against a broad reading of Chevron; he believes that for major questions, courts should make an independent assessment of statutory meaning, and not defer to reasonable interpretations by the executive branch. But why? The answer appears to be that reasonable legislators would want courts to assume an independent role (p. 106). But is this so clear? Assume that a statute-say, the Endangered Species Act, or the Food and Drug Act-contains an ambiguous provision on an issue of national importance. Might not reasonable legislators want a specialized, accountable agency to resolve the ambiguity, even on major questions?

On pragmatic grounds, it might be thought that resolution of the ambiguity often calls for a difficult policy judgment, and reasonable legislatures might not want difficult policy judgments to be made by federal courts. ${ }^{75}$ On consequentialist grounds, consider the following fact: In reviewing agency interpretations of law, Republican appointees to the federal bench show a definite "tilt" in a conservative direction, and Democratic appointees should a definite "tilt" in a liberal direction. ${ }^{76}$ Why would we think that a reasonable legislator would want statutory ambiguities to be resolved in accordance with whatever "tilt" can be found on the relevant reviewing court? Or consider an additional fact: A more refined approach to Chevron, of the sort that Breyer celebrates, has

\footnotetext{
${ }^{74}$ See Adrian Vermeule, Judging Under Uncertainty, forthcoming; Cass R. Sunstein and Adrian Vermeule, Institutions and Interpretation, 101 Mich L Rev 885 (2003).

${ }^{75}$ This argument is spelled out in some detail in Cass R. Sunstein, Beyond Marbury: The Executive's Power to Interpret the Law, Yale LJ (forthcoming).

${ }^{76}$ See id; Cass R. Sunstein and Thomas Miles, Do Judges Make Regulatory Policy? An Empirical Investigation of Chevron, U Chi L Rev (forthcoming).
} 
produced a great deal of confusion in the lower courts. ${ }^{77}$ Does pragmatism support that outcome?

In short, it is not clear that in this context, Breyer has properly identified the (hypothetical, constructed) instructions of a reasonable legislator; but the important point is far more general. For interpreting statutes, Breyer follows Hart and Sacks in arguing in favor of close attention to purposes, understood as the objectives of a "reasonable legislator." Sometimes this approach is indeed useful, especially where there is a consensus on what reasonableness requires. ${ }^{78}$ But Hart and Sacks, writing in the consensus-pervaded (and complacent) legal culture of the 1950s, downplayed the possibility that disagreement, highly ideological in nature, would break out on that question. In the current period, it should be obvious that different judges may well disagree about what a reasonable legislator would like to do. Imagine that a law condemns "discrimination on the basis of sex"; suppose that a state adopts a height and weight requirement for police officers, one that excludes far more women than men. In deciding whether this requirement is "discrimination," how shall judges characterize the purpose of a reasonable legislator? It is inevitable that courts will see their own preferred view as reasonable. Does that promote active liberty? Does pragmatism support a situation in which judges assess reasonableness by their own lights?

Unfortunately, the problem is common. Laws rarely come with clear announcements of their purposes, and in hard cases, any characterization requires some kind of evaluative judgment from courts. It is not a matter of finding something. Suppose that the antidiscrimination statute is invoked against affirmative action programs. ${ }^{79}$ Does the purpose of the ban on “discrimination” argue for, or against, such programs? It would be easy to characterize the purpose as the elimination of any consideration of race from the relevant domain; it would also be easy to characterize the purpose as the protection of traditionally disadvantaged groups. ${ }^{80}$ If judges are asked to say what "reasonable"

\footnotetext{
77 See Adrian Vermeule, Mead in the Trenches, 71 Geo Wash L Rev 347 (2003); Lisa Bressman, Vanderbilt L Rev (forthcoming).

${ }^{78}$ Examples are given in Stephen Breyer, On the Uses of Legislative History in Interpreting Statutes, 65 So. Cal. L. Rev.845 (1992).

${ }^{79}$ See United Steelworkers of America v. Weber, 443 US 193 (1979).

${ }^{80}$ See Ronald Dworkin, How to Read the Civil Rights Act, in A Matter of Principle 316 (1985).
} 
legislators would like to do, they are all too likely to say what they themselves would like to do.

Hart and Sacks, Breyer's predecessors, do offer a powerful and sensible approach to statutory interpretation, but they devote too little attention to the problem of characterizing purpose. When courts choose one purpose over another (reasonable) candidate, they are actually attempting to put the relevant text in the best constructive light. ${ }^{81}$ Of course they are selecting an interpretation that fits the text and context; if they were not doing that, they would not be engaging in interpretation at all. But when they select a reasonable purpose, they are choosing an approach that, by their own lights, makes the best sense. A judicial judgment on this count is hardly untethered-that would be a caricature—but it is a judicial judgment nonetheless.

Many textualists distrust resort to purposes for this very reason. Emphasizing the increasing substitution of statutes for the common law, they want courts to hew closely to statutory language. ${ }^{82}$ They think that judges have paid too little attention to the rise of statutory lawmaking, and have used common law approaches, including analogical reasoning, in domains where they do not belong. ${ }^{83}$ And indeed, the Hart and Sacks materials might well be understood as a product of an early confrontation between common law thinking and a system of law that is pervaded by statutory interventions. Justice Scalia believes that an emphasis on the plain meaning of the text, which is what after all has been enacted, promotes democratic responsibility and also helps to discipline the judiciary. ${ }^{84}$

If purpose is being characterized in a way that defies the ordinary meaning of the text, Scalia's argument has considerable pragmatic force. Indeed, textualism might easily be defended with reference to active liberty, and in two different ways. First, textualism promotes democratic government, by encouraging the legislature to make its instructions clear. Over time, a text-oriented judiciary might well promote better accountability from

\footnotetext{
${ }^{81}$ See Ronald Dworkin, Law’s Empire (1985).

${ }^{82}$ See Scalia, supra note.

${ }^{83} \mathrm{Id}$.

${ }^{84}$ See Scalia, A Matter of Interpretation, supra note.
} 
legislatures. Second, textualism disciplines judicial creation of "intentions" and "purposes" to push statutes in judicially preferred directions. ${ }^{85}$

To be sure, it is easy to overstate the constraints imposed by text. Where the text is ambiguous, or leaves gaps, textualism by hypothesis is inadequate, and some other interpretive tool must be invoked. ${ }^{86}$ There is a serious risks that in hard cases, preferences are likely to matter for textualists as for everyone all else. ${ }^{87}$ My only suggestion is that Breyer pays too little attention to the risk that any judgments about "reasonableness" will be the judges' own, in a way that disserves democracy itself.

Breyer is correct to say that any theory of interpretation has to be defended in terms of its consequences. But for interpreting statutes, it is not at all clear that a purposebased approach, focusing on consequences in particular cases, is preferable to a textbased approach, one that asks judges not to think little or not at all about consequences. A textual approach might be simpler to apply; if so, that is surely a point in its favor. And if judges cannot reliably identify reasonable purposes, textualism might also lead to better results, or consequences, all things considered. ${ }^{88}$

None of this means that Scalia's approach is necessarily superior to Breyer's. But it does point out the necessity of engaging the possibility that on his own consequentialist grounds, and with an eye firmly on democratic goals, textualism in the interpretation of

\footnotetext{
${ }^{85}$ Note in this regard the very different reaction of German and Italian judges to the emergence of fascism. German judges proceeded in a purposive fashion, abandoning text in favor of legislative goals (and consequences!) - in a way that promoted injustice an even atrocity. See Ingo Muller, Hitler's Justice: The Courts of the Third Reich(1991). By contrast, the Italian judges made close attention to text and to plain meaning, in a way that produced much better consequences. See Guido Calabresi, Two Functions of Formalism, 67 U Chi L Rev 479 (2000), and in particular this suggestion: "To the scholars opposing Fascism, the nineteenth-century self-contained formalistic system became a great weapon. . . . What it conserved was the liberal, nineteenth century political approach . . . [and] in a time of Fascism, the important thing was that it conserved basic democratic attitudes.” Id. at 482.

${ }^{86}$ Consider, for example, the rule of lenity, invoked in Smith v. US, 508 US 223 (1999) (Scalia, J, dissenting).

${ }^{87}$ Evidence can be found in Cass R. Sunstein, Beyond Marbury: The Executive’s Power to Interpret the Law; Cass R. Sunstein and Thomas Miles, Do Judges Make Regulatory Policy? An Empirical Investigation of Chevron, U Chi L Rev.

${ }^{88}$ Some people appear to believe that interpretation, to count as such, necessarily calls for attention to the "intent" of those who wrote the text in question. See, e.g., Stanley Fish [citation to be added]. This is a blunder. In law, it is certainly possible to interpret texts by pointing to the ordinary meaning of the words, without speculating about authorial intentions. Whether this is desirable as well as possible is another question, one that must be resolved by reference, among other things, to consequences.
} 
ordinary statutes might be better than an approach that explores purposes. ${ }^{89}$ Of course textualism is sometimes a fake, as when the text does not have any clear meaning. In my view, hard cases, in which the text is indeterminate, are best resolved with clear reference to the views of any applicable administrative agency, and also with close attention to pertinent canons of construction — which, properly used, discipline the exercise of judicial discretion and also serve the system of separated powers. ${ }^{90}$ But this is not the place to defend that view. The only point is that Breyer has not shown that a purposive approach to statutory interpretation is unambiguously preferable to the reasonable alternatives.

\section{Active Liberty As an Interpretive Tool}

Breyer is right to say that the framers wanted to recognize both active liberty and negative liberty. But the framers saw themselves as republicans, not as democrats, ${ }^{91}$ and they did not believe in participatory democracy or in rule through town meetings. On this count, Breyer slides quickly over intense debates about what the American framers actually sought to do. ${ }^{92}$ Of course they attempted to provide a framework for a form of self-government. ${ }^{93}$ But so stated, that goal operates at an exceedingly high level of abstraction, one that cannot easily be brought to bear on concrete cases. Much of the time, it is hard to link the general idea of self-government to particular judgments about contemporary disputes in constitutional law.

Certainly Breyer does not try to argue, in originalist fashion, that the actual drafters and ratifiers of the Constitution wanted to allow campaign finance reform, restrictions on commercial advertising, affirmative action programs, and federal commandeering of state government. He argues instead that the idea of active liberty, which animates the Constitution, helps to justify these judgments. This is reasonable enough. But exactly what kind of argument is it? The framers of the Constitution also

89 See Adrian Vermeule, Interpretive Choice, 75 NYU L Rev; 74 (2000); Adrian Vermeule, forthcoming book.

${ }^{90}$ See Sunstein, Beyond Marbury, supra note; Cass R. Sunstein, Nondelegation Canons, 67 U Chi L Rev. 315 (2000).

91 See Gordon Wood, The Creation of the American Republic (1969); Cass R. Sunstein, Interest Groups in American Public Law, 38 Stan L Rev 29 (1985)

92 See JGA Pocock, The Machiavellian Moment (rev ed 2003); Joseph Bessette, The Mild Voice of Reason (1985); Wood, supra note; Jack Rakove, Original Meanings (1997).

93 See Wood, supra note, 
placed a high premium on "domestic tranquility," to which the preamble explicitly refers. Would it be right to say that because domestic tranquility is a central goal of the document, the President is permitted to ban dangerous speech—or that because, or if, affirmative action threatens to divide the races, in a way that compromises "tranquility," color-blindness is the right principle after all?

In any case Breyer rightly emphasizes that the Constitution attempts to protect negative liberty too. Why shouldn't a ban on campaign finance restrictions be seen to run afoul of that goal? Nor is negative liberty the only value at stake. Such restrictions forbid people from spending their money on political campaigns, in a way that might well be taken to compromise participatory self-government. In this light we might well see campaign finance restrictions as offending, at once, both negative and active liberty. Deductive logic cannot take us from an acknowledgement of the importance of active liberty to acceptance of campaign finance restrictions; there are no syllogisms here. Instead an evaluative judgment must be made, to the effect that properly characterized, the first amendment and its goal of self-government do not condemn (the relevant) restriction on campaign contributions and expenditures. I believe that this conclusion is broadly correct, especially when we consider the general need for courts to defer to congressional judgments in hard cases. ${ }^{94}$ But the evaluative judgment is inescapable.

Or suppose that we accept, as we should, Breyer's claims about the centrality of active liberty to the constitutional design. Is originalism therefore off the table? Not at all. We might believe, with some constitutional theorists (including Alexander Hamilton ${ }^{95}$ ), that constitutional provisions, as products of an engaged citizenry, reflect the will of We the People, as ordinary legislation usually does not. If so, an emphasis on the original understanding can be taken to serve active liberty at the same time that it promotes negative liberty. It serves active liberty because it follows the specific judgments of an engaged citizenry. It promotes negative liberty because and precisely to the extent that those judgments favor negative liberty (or for that matter active liberty). I do not mean to suggest that this argument is convincing. The framers and ratifiers included only a small

\footnotetext{
${ }^{94}$ An obvious qualification involves incumbent protection measures. If campaign finance legislation is operating to insulate incumbents against electoral challenge, there is a strong reason, on grounds of active liberty (among others), for courts to take a strong role.

${ }^{95}$ See The Federalist No. 78; see also Bruce Ackerman, We the People vol. 1: Foundations (1993).
} 
segment of early America, and in any case the fact that the framers and ratifiers are long dead creates serious problems for those who argue for originalism in democracy's name. The only point is that Breyer's emphasis on active liberty does not rule originalism out of bounds.

Or return to Thayer's claim that the Court should strike down legislation only if it clearly and unambiguously violates the Constitution. Despite his general enthusiasm for restraint, Breyer does not mean to follow Thayer. But why not? Thayer and his followers can claim to favor active liberty, because they allow the sovereign people to do as they choose. Indeed, Learned Hand, an apostle of judicial restraint, wanted courts to be reluctant to invalidate legislation in large part because he was committed democratic selfrule. ${ }^{96}$ Perhaps Breyer thinks that this approach undervalues both negative and active liberty. But why? Perhaps a deferential Court will ultimately produce exactly the right mix between the two kinds of freedom. Of course Ely's approach, emphasizing reinforcement of democratic processes, can easily be rooted in active liberty; indeed, active liberty lies at its heart. Breyer writes approvingly of the Warren Court on the ground that its decisions promoted active liberty (p. 11); and Ely is the Warren Court's most systematic defender. Does Breyer mean to endorse Ely? If not, where does he differ? A puzzling gap in Breyer's book is the omission of any treatment of Ely's apparently similar argument. ${ }^{97}$

Recall that Breyer candidly acknowledges that legislative "purpose" is not something that can simply be found. "Purpose" is what judges attribute to the legislature, based on their own conception of what reasonable legislators would mean to do. If this is true for the purposes of individual statutes, it is also true for the purposes of the Constitution as well. When Breyer says that the "basic" purpose of the Constitution is to protect active liberty, so as to produce concrete conclusions on disputed questions, his own judgments about the goals of a reasonable constitution-maker are playing a central role. Fortunately, Breyer's own judgments are indeed reasonable. But he underplays the extent to which they are his own.

\footnotetext{
${ }^{96}$ See Learned Hand, The Spirit of Liberty (Irving Dillard ed. 1960)/

${ }^{97}$ There is only one reference to Ely, presaged by "cf" see p. 1146. Note also that Frank Michelman has made closely related arguments. See Frank Michelman, Traces of Self-Government, 100 Harv L Rev. 4 (1986).
} 
The same point bears on Breyer's enthusiasm for an inquiry into consequences. Consequences certainly do matter, but much of the time, it is impossible to assess consequences without reference to disputed questions of value. Return to the question of affirmative action, and suppose, rightly, that the text of the Constitution could, but need not, be understood to require color-blindness. If we care about consequences, will we accept the color-blindness principle or not? Suppose we believe that affirmative action programs create racial divisiveness and increase the risk that underqualified people will placed in important positions. If those are bad consequences, perhaps we will oppose affirmative action programs. An emphasis on consequences as such is only a start. Of course Breyer is not concerned with consequences alone; he wants to understand them with close reference to specified purposes, above all "active liberty." But as I have suggested, that idea, taken in the abstract, is compatible with a range of different approaches to constitutional law; it need not be taken to compel Breyer's own approach.

None of this means that Breyer is wrong. On the contrary, I believe that he is largely right. He is right to say that the free speech principle should be understood to democratic terms. He is right to say that where the Court lacks important information, it should rule cautiously and narrowly. He is right to resist the constitutional assault on affirmative action programs (an assault that, by the way, is extremely hard to defend in originalist terms ${ }^{98}$ ). He is right to reject originalism. Above all, he is right to emphasize the importance of democratic goals to constitutional interpretation.

But to make his argument convincing, he would have to offer a more sustained encounter between his own approach and the imaginable alternatives. Essentially for Breyer's own reasons, originalism does seem unacceptable, certainly if it is unaccompanied by respect for precedent; and it is not clear if originalism, so accompanied, can be made coherent. Bipartisan restraint, of the sort championed by Thayer and Holmes, has many attractions, and the Court should probably move toward it in some areas ${ }^{99}$; but in too many contexts, it too would destabilize our rights and our institutions. For the evaluation of a democracy-centered approach to constitutional law, a great deal depends on whether courts will often wield democratic ideals as a sword

\footnotetext{
${ }^{98}$ See Eric Schnapper, Affirmative Action and the Legislative History of the Fourteenth Amendment, 71 Va L Rev. 753 (1985).

${ }^{99}$ See Vermeule, supra note.
} 
against our actual democracy (as Ely urged), or whether they will more frequently use those ideals as a shield against constitutional attacks (as Breyer appears to urge). A great deal also depends on our degree of trust in those who wield those ideals, and their likely reasonableness.

A deeper point lies in the background here. For the selection of a general theory of interpretation, a great deal turns on context. I have argued against originalism, but it is possible to imagine a world in which originalism would make a great deal of sense. Suppose, for example, that the original public meaning of the founding document would generally or always produce sensible results; that violations of the original public meaning would be unjust or otherwise unacceptable; that democratic processes that did not violate the original public meaning would not cause serious problems from the standpoint of justice or otherwise; and that judges, not following the original public meaning, would produce terrible blunders from the appropriate point of view. In such a world, originalism would be the best approach to follow. I have argued against bipartisan restraint. But in a world in which democratic processes were systematically reliable, and in which unrestrained judges would use ambiguous provisions of the Constitution to impose unjust or otherwise unsupportable policies, the argument for bipartisan restraint would be very strong. The larger point is that the Constitution itself does not contain a theory of interpretation, and no single theory would make sense in every imaginable world.

It is also possible to doubt whether the Supreme Court should accept any ambitious or unitary theory of interpretation. ${ }^{100}$ Perhaps the Court does best, in our actual world, if it avoids ambitious accounts, and decides cases, if it can, with reference to reasons that can command agreement from those with diverse views about foundational questions, and from those who do not want to take a stand on those questions. Perhaps a commitment to "active liberty" is too sectarian to command general assent. But at least this much can be said on Breyer's behalf: If an ambitious account is desirable, indispensable, or unavoidable, an emphasis on the commitment to democratic rule is hardly the worst place to start.

${ }^{100}$ See Cass R. Sunstein, Incompletely Theorized Agreements, 108 Harv L Rev 1733 (1995); Cass R. Sunstein, One Case At A Time (1999). 


\section{Conclusion}

Within the Supreme Court itself, the most powerful recent theoretical arguments have come from Justice Scalia, with his insistence on originalism and his complaint that if courts are not bound by the original understanding, they are essentially doing whatever they want. ${ }^{101}$ Breyer has now developed a distinctive argument of his own, one that demonstrates the possibility of a nonoriginalist method that, while not eliminating discretion, is hardly a blank check to the judiciary. Breyer's originality lies in the effort to forge links among its three distinctive moving parts: an appreciation of "active liberty" and its place in our constitutional tradition; a commitment to purposive understandings of interpretation; and an insistence, inspired by American pragmatism, that theories of interpretation must be evaluated in terms of their consequences.

I have emphasized what seems to me a central problem in Breyer's account: the difficulty of characterizing purposes, and of counting purposes as "reasonable," without a judgment of the interpreter's own. In hard cases, judgments about purpose are evaluative, not descriptive. ${ }^{102}$ What is true for particular provisions is true for the founding document as a whole. Active liberty is certainly a theme of the document, but it is not easy to deduce, from that theme, particular conclusions about the legal issues raised campaign finance restrictions, affirmative action plans, privacy, and judicial review of agency action. Nor does active liberty, standing alone, make the choice between textual and purposive approaches to constitutional interpretation. On purely pragmatic grounds, purposive approaches run into serious problems once we acknowledge the role of judicial discretion in the characterization of purposes. ${ }^{103}$

I have also suggested the possibility of endorsing a kind of second-order pragmatism, one that attempts to develop tools to discipline the judicial inquiry into both consequences and purposes. Perhaps we are all pragmatists now, in the sense that we can agree that any theory of interpretation must pay close attention to the outcomes that it

\footnotetext{
101 See Scalia, supra note.

102 This point is emphasized and not deplored in Dworkin, Law’s Empire, supra note; Insofar as he emphasizes the constructive element in interpretation, Dworkin seems to me to make a large advance on Hart and Sacks, whose approach resembles his.

${ }^{103}$ Cf. Vermeule, supra note.
} 
produces. ${ }^{104}$ Whether or not we do agree on that point, we certainly should. The problem is that many diverse views can march under the pragmatic banner.

But if Breyer's particular conclusions are not compelled by his general themes, they are always plausible, and usually more than that. Many originalists fear that without originalism, judges will be unloosed, producing a system of interpretation that endangers self-government and is extremely hard to defend in terms of its consequences. One of the many virtues of Breyer's book is its demonstration that these objections are overstatedthat without mechanical jurisprudence or rule-

Readers with comments should address them to:

Professor Cass Sunstein

University of Chicago Law School

1111 East 60th Street

Chicago, IL 60637 csunstei@uchicago.edu

${ }^{104}$ Note that even Dworkin describes himself as a consequentialist. See Ronald Dworkin, Order of the Coif Lecture: In Praise of Theory, 29 Ariz. St. L. J. 353, 364 (1997). 


\section{Chicago Working Papers in Law and Economics (Second Series)}

For a listing of papers 1-174 please go to Working Papers at http://www.law.uchicago.edu/Lawecon/index.html

175. Douglas G. Baird, In Coase's Footsteps (January 2003)

176. David A. Weisbach, Measurement and Tax Depreciation Policy: The Case of Short-Term Assets (January 2003)

177. Randal C. Picker, Understanding Statutory Bundles: Does the Sherman Act Come with the 1996 Telecommunications Act? (January 2003)

178. Douglas Lichtman and Randal C. Picker, Entry Policy in Local Telecommunications: Iowa Utilities and Verizon (January 2003)

179. William Landes and Douglas Lichtman, Indirect Liability for Copyright Infringement: An Economic Perspective (February 2003)

180. Cass R. Sunstein, Moral Heuristics (March 2003)

181. Amitai Aviram, Regulation by Networks (March 2003)

182. Richard A. Epstein, Class Actions: Aggregation, Amplification and Distortion (April 2003)

183. Richard A. Epstein, The "Necessary" History of Property and Liberty (April 2003)

184. Eric A. Posner, Transfer Regulations and Cost-Effectiveness Analysis (April 2003)

185. Cass R. Sunstein and Richard H. Thaler, Libertarian Paternalizm Is Not an Oxymoron (May 2003)

186. Alan O. Sykes, The Economics of WTO Rules on Subsidies and Countervailing Measures (May 2003)

187. Alan O. Sykes, The Safeguards Mess: A Critique of WTO Jurisprudence (May 2003)

188. Alan O. Sykes, International Trade and Human Rights: An Economic Perspective (May 2003)

189. Saul Levmore and Kyle Logue, Insuring against Terrorism - and Crime (June 2003)

190. Richard A. Epstein, Trade Secrets as Private Property: Their Constitutional Protection (June 2003)

191. Cass R. Sunstein, Lives, Life-Years, and Willingness to Pay (June 2003)

192. Amitai Aviram, The Paradox of Spontaneous Formation of Private Legal Systems (July 2003)

193. Robert Cooter and Ariel Porat, Decreasing Liability Contracts (July 2003)

194. David A. Weisbach and Jacob Nussim, The Integration of Tax and Spending Programs (September 2003)

195. William L. Meadow, Anthony Bell, and Cass R. Sunstein, Statistics, Not Memories: What Was the Standard of Care for Administering Antenatal Steroids to Women in Preterm Labor between 1985 and 2000? (September 2003)

196. Cass R. Sunstein, What Did Lawrence Hold? Of Autonomy, Desuetude, Sexuality, and Marriage (September 2003)

197. Randal C. Picker, The Digital Video Recorder: Unbundling Advertising and Content (September 2003)

198. Cass R. Sunstein, David Schkade, and Lisa Michelle Ellman, Ideological Voting on Federal Courts of Appeals: A Preliminary Investigation (September 2003)

199. Avraham D. Tabbach, The Effects of Taxation on Income Producing Crimes with Variable Leisure Time (October 2003)

200. Douglas Lichtman, Rethinking Prosecution History Estoppel (October 2003)

201. Douglas G. Baird and Robert K. Rasmussen, Chapter 11 at Twilight (October 2003)

202. David A. Weisbach, Corporate Tax Avoidance (January 2004)

203. David A. Weisbach, The (Non)Taxation of Risk (January 2004)

204. Richard A. Epstein, Liberty versus Property? Cracks in the Foundations of Copyright Law (April 2004)

205. Lior Jacob Strahilevitz, The Right to Destroy (January 2004)

206. Eric A. Posner and John C. Yoo, A Theory of International Adjudication (February 2004)

207. Cass R. Sunstein, Are Poor People Worth Less Than Rich People? Disaggregating the Value of Statistical Lives (February 2004) 
208. Richard A. Epstein, Disparities and Discrimination in Health Care Coverage; A Critique of the Institute of Medicine Study (March 2004)

209. Richard A. Epstein and Bruce N. Kuhlik, Navigating the Anticommons for Pharmaceutical Patents: Steady the Course on Hatch-Waxman (March 2004)

210. Richard A. Esptein, The Optimal Complexity of Legal Rules (April 2004)

211. Eric A. Posner and Alan O. Sykes, Optimal War and Jus Ad Bellum (April 2004)

212. Alan O. Sykes, The Persistent Puzzles of Safeguards: Lessons from the Steel Dispute (May 2004)

213. Luis Garicano and Thomas N. Hubbard, Specialization, Firms, and Markets: The Division of Labor within and between Law Firms (April 2004)

214. Luis Garicano and Thomas N. Hubbard, Hierarchies, Specialization, and the Utilization of Knowledge: Theory and Evidence from the Legal Services Industry (April 2004)

215. James C. Spindler, Conflict or Credibility: Analyst Conflicts of Interest and the Market for Underwriting Business (July 2004)

216. Alan O. Sykes, The Economics of Public International Law (July 2004)

217. Douglas Lichtman and Eric Posner, Holding Internet Service Providers Accountable (July 2004)

218. Shlomo Benartzi, Richard H. Thaler, Stephen P. Utkus, and Cass R. Sunstein, Company Stock, Market Rationality, and Legal Reform (July 2004)

219. Cass R. Sunstein, Group Judgments: Deliberation, Statistical Means, and Information Markets (August 2004, revised October 2004)

220. Cass R. Sunstein, Precautions against What? The Availability Heuristic and Cross-Cultural Risk Perceptions (August 2004)

221. M. Todd Henderson and James C. Spindler, Corporate Heroin: A Defense of Perks (August 2004)

222. Eric A. Posner and Cass R. Sunstein, Dollars and Death (August 2004)

223. Randal C. Picker, Cyber Security: Of Heterogeneity and Autarky (August 2004)

224. Randal C. Picker, Unbundling Scope-of-Permission Goods: When Should We Invest in Reducing Entry Barriers? (September 2004)

225. Christine Jolls and Cass R. Sunstein, Debiasing through Law (September 2004)

226. Richard A. Posner, An Economic Analysis of the Use of Citations in the Law (2000)

227. Cass R. Sunstein, Cost-Benefit Analysis and the Environment (October 2004)

228. Kenneth W. Dam, Cordell Hull, the Reciprocal Trade Agreement Act, and the WTO (October 2004)

229. Richard A. Posner, The Law and Economics of Contract Interpretation (November 2004)

230. Lior Jacob Strahilevitz, A Social Networks Theory of Privacy (December 2004)

231. Cass R. Sunstein, Minimalism at War (December 2004)

232. Douglas Lichtman, How the Law Responds to Self-Help (December 2004)

233. Eric A. Posner, The Decline of the International Court of Justice (December 2004)

234. Eric A. Posner, Is the International Court of Justice Biased? (December 2004)

235. Alan O. Sykes, Public vs. Private Enforcement of International Economic Law: Of Standing and Remedy (February 2005)

236. Douglas G. Baird and Edward R. Morrison, Serial Entrepreneurs and Small Business Bankruptcies (March 2005)

237. Eric A. Posner, There Are No Penalty Default Rules in Contract Law (March 2005)

238. Randal C. Picker, Copyright and the DMCA: Market Locks and Technological Contracts (March 2005)

239. Cass R. Sunstein and Adrian Vermeule, Is Capital Punishment Morally Required? The Relevance of Life-Life Tradeoffs (March 2005)

240. Alan O. Sykes, Trade Remedy Laws (March 2005)

241. Randal C. Picker, Rewinding Sony: The Evolving Product, Phoning Home, and the Duty of Ongoing Design (March 2005)

242. Cass R. Sunstein, Irreversible and Catastrophic (April 2005)

243. James C. Spindler, IPO Liability and Entrepreneurial Response (May 2005)

244. Douglas Lichtman, Substitutes for the Doctrine of Equivalents: A Response to Meurer and Nard (May 2005)

245. Cass R. Sunstein, A New Progressivism (May 2005) 
246. Douglas G. Baird, Property, Natural Monopoly, and the Uneasy Legacy of INS v. AP (May 2005)

247. Douglas G. Baird and Robert K. Rasmussen, Private Debt and the Missing Lever of Corporate Governance (May 2005)

248. Cass R. Sunstein, Administrative Law Goes to War (May 2005)

249. Cass R. Sunstein, Chevron Step Zero (May 2005)

250. Lior Jacob Strahilevitz, Exclusionary Amenities in Residential Communities (July 2005)

251. Joseph Bankman and David A. Weisbach, The Superiority of an Ideal Consumption Tax over an Ideal Income Tax (July 2005)

252. Cass R. Sunstein and Arden Rowell, On Discounting Regulatory Benefits: Risk, Money, and Ingergenerational Equity (July 2005)

253. Cass R. Sunstein, Boundedly Rational Borrowing: A Consumer's Guide (July 2005)

254. Cass R. Sunstein, Ranking Law Schools: A Market Test? (July 2005)

255. David A. Weisbach, Paretian Intergenerational Discounting (August 2005)

256. Eric A. Posner, International Law: A Welfarist Approach (September 2005)

257. Adrian Vermeule, Absolute Voting Rules (August 2005)

258. Eric Posner and Adrian Vermeule, Emergencies and Democratic Failure (August 2005)

259. Douglas G. Baird and Donald S. Bernstein, Absolute Priority, Valuation Uncertainty, and the Reorganization Bargain (September 2005)

260. Adrian Vermeule, Reparations as Rough Justice (September 2005)

261. Arthur J. Jacobson and John P. McCormick, The Business of Business Is Democracy (September 2005)

262. Adrian Vermeule, Political Constraints on Supreme Court Reform (October 2005)

263. Cass R. Sunstein, The Availability Heuristic, Intuitive Cost-Benefit Analysis, and Climate Change (November 2005)

264. Lior Jacob Strahilevitz, Information Asymmetries and the Rights to Exclude (November 2005)

265. Cass R. Sunstein, Fast, Frugal, and (Sometimes) Wrong (November 2005)

266. Robert Cooter and Ariel Porat, Total Liability for Excessive Harm (November 2005)

267. Cass R. Sunstein, Justice Breyer's Democratic Pragmatism (November 2005)

268. Cass R. Sunstein, Beyond Marbury: The Executive's Poer to Say What the Law Is (November 2005) 